\title{
University/polytechnic distinction to end
}

\section{- Little change seen in research funding - Education on the election agenda}

\section{London}

THE division in British higher education between the universities and polytechnics should soon end. Saying that "The polytechnics have come of age," Prime Minister John Major launched on Monday (20 May) a series of reforms to education and training, including a plan to eliminate the distinction between the two types of institutions.

The first polytechnics were set up in the 1960 s to provide vocational education aimed at preparing students for jobs in industry and other professions. But now they are often seen as 'second class universities' by prospective students and employers alike.

Under Major's new proposal, the Universities Funding Council (UFC) and the Polytechnics and Colleges Funding Council (PCFC), both created in 1989, would be dissolved. They will be replaced by three new higher education funding councils, one each for England, Scotland and Wales, which will find both teaching and research across the whole higher education sector. Polytechnics will be able to call themselves universities, should they wish to do so.

The abolition of the traditional 'binary divide' in British higher education will allow the polytechnics to compete for students on level terms with the universities, Major said. And Sir Ron Dearing, PCFC chairman, and Lord Chilver, his counterpart at the UFC, issued a joint statement on Monday welcoming the proposed changes.

The decision by Major, who left school at sixteen, to launch the new initiative personally suggests that education will be a central issue in the next general election campaign. The opposition Labour party has already stated that the UFC and the PCFC would be merged, if Labour comes to power.

Many polytechnic directors have been pushing hard for the merger of the universities' and polytechnics' separate funding bodies (see Nature 349, 360; 31 January 1991). The directors would like some of the $£ 860$ million the UFC distributes each year for research in the universities to be made available to polytechnicc with a good record for research. (The PCFC's research budget in $1990-91$ was only about $£ 30$ million.)

The proposed new system, however, is unlikely to result in a major redistribution of British research spending. Education and Science Secretary Kenneth Clarke said there would be no wholesale transfer of research funds from the universities to the polytechnics. Under the system, the former polytechnics will merely be able to compete "in a limited way" for research money from the new funding councils, he said.
The higher education policy document does not rule out more radical reform of British research spending in future. In the long term, the research budgets of the new higher education funding councils may be transferred en masse, either to the research councils, or a new research funding agency.

Many polytechnics are expected to relaunch themselves as universities, once they are able to do so. But the change in title may be little more than a cosmetic exercise. Clarke said the new funding councils will be asked to ensure that the polytechnics do not change their mission. The former polytechnics should still concentrate on vocational education and applied research, the universities on academic subjects and pure research, he said.

The new system will also do little to silence the critics within the universities and polytechnics who claim that the government's policy of expanding higher education without a commensurate increase in public funding will erode the quality of British higher education. But the higher education policy document does propose that a new independent unit should be set up to monitor the quality of education across the higher education sector.

The package of policy documents released on Monday also include reforms to the education and training of sixteen-to nineteenyear-olds. The aim, according to Major, is to "break down the artificial barrier which has for too long divided an academic education from a vocational one". Young people will be free to take a mixture of A-levels, the traditional academic qualifications which form the standard entry requirement for higher education, and vocational qualifications.

But the government has not bowed to the calls for the replacement of A-levels with a system that does not channel students into a narrow range of academic subjects at sixteen. (Students in England and Wales aiming to enter higher education typically take three or four A-levels, each in a single subject.) Earlier this month, the Royal Society suggested that A-levels should be replaced by a single qualification within which students would be able to take a range of course modules, from a diverse range of subjects but the government rejected this.

Major said that the government would introduce legislation to enact the proposed reforms as soon as possible. But with a general election possible before the end of the year, the government may have to be reelected before the new policies are put into action.

Peter Aldhous

\section{Astro reborn}

\section{Washington}

AFTER a lobbying effort by Senator Barbara Mikulski (Democrat, Maryland), the National Aeronautics and Space Administration (NASA) has agreed to fly the "Astro" package of three ultraviolet telescopes on at least one more shuttle mission.

The package's first outing, called Astro1, was aboard the space shuttle Columbia last December. Despite a series of mechanical troubles and mishaps, it was operated almost continuously for 9 days by shuttle astronauts, who were guided by instructions from astronomers at Marshall Space Flight Center in Alabama (see Nature 348 571; 13 December 1990). The three telescopes obtained images and spectral and polarization data in ultraviolet wavelength bands inaccessible to ground-based astronomers; they were accompanied by a separate X-ray telescope which will not be flown again on Astro-2. The first scientific results from the Astro-1 mission were published in Nature two weeks ago $(351,128 ; 9$ May 1990).

In its original conception, the Astro package was designed to be flown at least six times, but after the inaugural launch was delayed first by the Challenger disaster of 1986 and then, in early 1990 , by a string of shuttle problems, it was unclear whether the demands on the shrinking shuttle launch manifest would permit it ever to be flown again. Mikulski, whose interest in Astro derives from the fact that two of its three telescopes were built in Maryland (at Johns Hopkins University and the Goddard Space Flight Center), intervened to persuade NASA to take Astro out of storage and put it back on the shuttle launch manifest.

David Lindley

FRENCH RESEARCH

\section{Science policy}

\section{from abroad}

\section{Washington}

Edith Cresson, the new prime minister of France, wants her country to have as much government support of industrial science as Japan and as many engineers as Germany. In one of her first acts in office, last week she consolidated the French ministries of finance, economics, foreign trade, industry and telecommunications into one "super-ministry" in a bid to emulate the power and influence exercised by the Japanese Ministry of International Trade and Industry.

She reappointed Pierre Beregovoy, finance minister, to lead the new agency, which will be the focus of the new prime minister's ambitious industrial policy - to fashion France into an economic power on the level of Germany.

ChristopherAnderson 